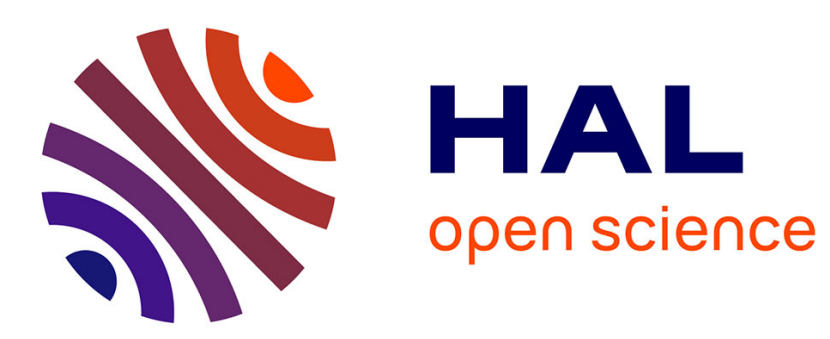

\title{
Book Review: Relative Intimacy: Fathers, Adolescent Daughters and Postwar American Culture. Pamela Dale
}

\section{To cite this version:}

Pamela Dale. Book Review: Relative Intimacy: Fathers, Adolescent Daughters and Postwar American Culture.. History of Psychiatry, 2006, 17 (2), pp.243-244. 10.1177/0957154X06066922 . hal00570862

\section{HAL Id: hal-00570862 \\ https://hal.science/hal-00570862}

Submitted on 1 Mar 2011

HAL is a multi-disciplinary open access archive for the deposit and dissemination of scientific research documents, whether they are published or not. The documents may come from teaching and research institutions in France or abroad, or from public or private research centers.
L'archive ouverte pluridisciplinaire HAL, est destinée au dépôt et à la diffusion de documents scientifiques de niveau recherche, publiés ou non, émanant des établissements d'enseignement et de recherche français ou étrangers, des laboratoires publics ou privés. 
History of Psychiatry, 17(2): 243-246 Copyright (C) 2006 SAGE Publications (London, Thousand Oaks, CA and New Delhi) www.sagepublications.com [200606] DOI: 10.1177/0957154X06066922

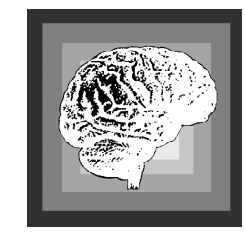

\section{Book Reviews}

\section{Rachel Devlin. Relative Intimacy: Fathers, Adolescent Daughters and Postwar American Culture. Chapel Hill [USA] and London: The University of North Carolina Press, 2005. Pp. ix + 254. ISBN 0-8078-5605-3 (pbk). \$19.95.}

This book clearly originated in a dissertation, allowing Rachel Devlin to use Relative Intimacy to develop an extremely novel thesis based on the close reading of an incredible wealth of source material. On many levels, Relative Intimacy provides an engaging and thought-provoking read for those engaged in the history of psychiatry, as well as those concerned with gender and cultural history. Devlin points to a shift in discussion about adolescent girls in psychiatric literature from 'father-fixation' to 'Oedipal conflict' in the 1940s and draws extensively on the sadly neglected work of Helene Deutsch. This professional post-war view of the problems of adolescence, and the centrality of the father-figure, offers an interesting counterview to better known contemporary concern with maternal deprivation and its implications for the care of very young children. While influential men like Bowlby and Spock addressed the vexed problem of baby-care, female practitioners were unusually prominent in debates about the emotional needs and social adjustment of adolescent girls. Devlin shows the way these debates were harnessed to limit the potential of female emancipation, but they also contained the possibility of prescribing and proscribing certain roles for adult men, at least in the context of fatherhood.

This is interesting material, and Devlin argues her case well. But the book is most innovative when focus shifts from the professional literature to the 'popularization' of theories originating in psychoanalysis. The popular interest in, and appeal of, Freudian ideas is especially noteworthy for Devlin. She is by no means the first commentator to hypothesize that lay audiences found the broad concepts easy to grasp, and part of the fun in testing them out on family and friends were the deeper, even dangerous, truths apparently revealed. Yet Devlin goes further than many by arguing that this allowed for a 'sophisticated' reception for a variety of books and plays that dealt with the theme of fatherdaughter incest. For Devlin the success of Lolita was not due to its content being regarded as scandalous but its ability to speak to an audience familiar with the 'relentless eroticization of the father-daughter relationship on all levels of culture' (p. 170). 
Devlin is, however, explicitly writing about a uniquely American culture at a very specific historical moment. This presents some difficulties for an international audience for whom important coming-of-age dramas like the 'junior prom' lack the intimacy of personal experience. While this does nothing to invalidate Devlin's argument, it creates some problems of understanding when nuance is clearly so vital to a full appreciation of her work. Once alert to the importance of cultural differences, a number of other points occur to the reader. Devlin is talking about post-war culture, but many of the key texts she identifies either originate in the years 1939-45 or draw on other work from this earlier period. Although Devlin acknowledges the impact of wartime disruption, the British reader cannot help but give more weight to the problem of family separation than father-daughter bonding, and feel that it is rationing rather than 'shared consumerism' that shaped many social attitudes and rituals in this period. This is not hugely important, as Devlin does not seek to look beyond the USA, but European readers would instinctively give a greater role to the state in shaping family policy, especially in the management of juvenile delinquency. They would also appreciate more information than Devlin gives about the audience for the American books, plays, magazines and films that she analyses. Nonetheless Devlin should be congratulated on making the apparently safe and familiar world of 1950s domesticity so interestingly disturbing.

Pamela Dale

University of Exeter

Daniel Pick and Lyndal Roper (eds). Dreams and History. The Interpretation of Dreams from Ancient Greece to Modern Psychoanalysis. London and New York: Brunner-Routledge, 2004. Pp. 276. ISBN 1-58391-282-5 (pbk).

This collection contains an essay-length introduction to the topic of dreams in Western history, followed by thirteen essays, twelve of which were previously published between 1999 and 2002. The collection offers the historian and educated reader a sampling of current scholarship on the cultural history of attitudes towards dreams, fantasies and related mental states, written by scholars from art history, anthropology, history of religion, medicine, psychiatry and psychoanalysis.

Organized chronologically, the collection begins with anthropologist Charles Stewart's challenge to Freud's conclusion that the Greeks were less repressed than moderns: 'Oedipus was tragic but Hamlet was neurotic.' Historian HansJürgen Bachorski contrasts three uses of dreams in medieval German literature, and raises the larger issue of how one can approach a dream text psychoanalytically when the dreamer is a fictional character.

Most of the essays in the collection are on topics in the seventeenth to nineteenth centuries, including a discussion of the recorded dreams of English 